MINIREVIEWS

UDC 576.535

\title{
Role of poly(ADP-ribose)polymerase 2 in DNA repair
}

\author{
S. N. Khodyreva, M. M. Kutuzov, O. I. Lavrik \\ Novosibirsk Institute of Chemical Biology and Fundamental Medicine, Siberian Branch of the Russian Academy of Sciences \\ 8, Akademika Lavrentieva Ave., Novosibirsk, Russian Federation, 630090 \\ svetakh@niboch.nsc.ru
}

\begin{abstract}
Poly(ADP-ribosyl)ation is a posttranslational protein modification significant for the genomic stability and cell survival in response to DNA damage. Poly(ADP-ribosyl)ation is catalyzed by poly(ADP-ribose)polymerases (PARPs), which use $N A D^{+}$as a substrate, synthesize polymer of (ADP)-ribose (PAR) covalently attached to nuclear proteins including PARP themselves. PARPs constitute a large family of proteins, in which PARP1 is the most abundant and best-characterized member. In spite of growing body of PARPs' role in cellular processes, PARP2, the closest homolog of PARP1, still remains poorly characterized at the level of its contribution to different pathways of DNA repair. An overview summarizes in vivo and in vitro data on PARP2 implication in specialized DNA repair processes, base excision repair and double strand break repair.
\end{abstract}

Keywords: PARP2, poly(ADP-ribosyl)ation, DNA repair.

Introduction. Poly(ADP-ribosyl)ation is a posttranslational protein modification significant for genomic stability and cell survival in response to DNA damage [1]. Poly(ADP-ribosyl)ation is catalyzed by poly(ADP-ribose)polymerases (PARPs). PARPs now constitute a large family of 17 proteins displaying a conserved catalytic domain, in which PARP1, PARP2 and PARP3 are known to become catalytically active in response to DNA damage [1]. Once activated, the enzymes using $\mathrm{NAD}^{+}$catalyze synthesis of ADP-ribose polymer (PAR) attached to the acceptor proteins and to itself. The most evident effects of protein poly(ADP-ribosyl)ation on regulation of DNA repair involves: i) providing the DNA repair machinery access to damaged DNA via loosening of the poly(ADP-ribosyl)ated protein binding to DNA due to electrostatic repulsion of negatively charged PAR and DNA; ii) recruitment of the repair proteins to DNA damages via direct interaction with PAR attached to proteins [1].

PARP1, since its discovery, has long being considered as the only PARP capable for activation by DNA damages. A new DNA damage-dependent PARP, named PARP2, was discovered because of residual PAR

(C) Institute of Molecular Biology and Genetics, NAS of Ukraine, 2012 synthesis detected in PARP1-deficient cells [2]. Recombinant PARP2 was shown to be activated by DNA (DNase I treated) and synthesizes PAR [2]. PARP1 and PARP2 differ in the structure of their DNA-binding domains and may recognize not identical types of DNA lesions [2]. As a whole, PARP2 is much less active than PARP1, despite of high homology of their catalytic domains [2]. PARP1 and PARP2 also differ in their protein-protein interaction domains, and this may result in differential responses caused by specific partner recruitment. Although PARP1 and PARP2 functions could

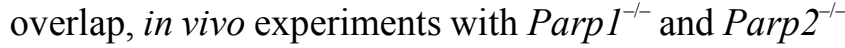
mice demonstrated that lack of each of them could not be fully compensated by another one [2].

PARP2 in base excision repair/single-strand break repair. Base excision repair (BER) and singlestrand break repair (SSBR) are closely related processes that differ at early steps and share functions of enzymes and co-factor proteins acting at the stages after DNA strand incision [3]. BER/SSBR system takes part in repair of DNA damages induced by alkylating and oxidizing reagents and ionizing radiation [3]. PARP1 is a well-known player in regulation of BER/SSBR [3] while implication of PARP2 in these processes is insufficiently characterized [1]. PARP2 was shown to physi- 
cally and/or functionally interact with BER proteins, PARP1, XRCC1, DNA polymerase $\beta$, and DNA ligase III [4]. XRCC1 negatively regulates activity of PARP1 and PARP2, and is a PAR acceptor for both PARPs. The physiological role of PARP2 in response to genotoxic stress was confirmed in mice and cells with disrupted gene encoding PARP2 [4]. In response to treatment by the alkylating agent $N$-nitroso- $N$-methylurea, PARP2 deficient cells displayed an important delay in DNA strand breaks resealing, thus confirming the active role of PARP2 in BER despite its low capacity for PAR synthesis. Moreover, several lines of evidence allow to propose PARP2 involvement in BER at later stages as compared to PARP1 [4].

PARP2 in double strand break repair. Double strand breaks repair (DSBR) in higher eukaryotes is carried out through the two unrelated DNA repair pathways, non-homologous end joining (NHEJ) and homologous recombination (HR) [3]. HR uses the regions of DNA homology (sister chromatid or homologous chromosome) as coding information. NHEJ based on simple end rejoining is presented by two pathways: $\mathrm{Ku}$ antigen dependent (main) and $\mathrm{Ku}$ antigen independent (alt-NHEJ), which involves the BER protein machinery - PARP1, DNA polymerase $\beta$, and DNA ligase III/ XRCC1 [5]. Along with DSBs produced by DNA damaging agents, they are also resulted from collapse of DNA replication forks at SSB persisting in DNA and appear as intermediates in normal physiologic processes, V(D)J recombination and class switch (CS) recombination (CSR), which are required for diversification of T-cell receptors and immunoglobulin repertoire [5].

Proteome-wide search of PARP2 interactors by affinity-purification combined with mass spectrometry revealed physical interaction of PARP 2 with $\mathrm{Ku} 70$ and $\mathrm{Ku} 80$, which together are known as DNA binding component of DNA dependent protein kinase (DNA PK). Heterotrimeric complex composed of $\mathrm{Ku} 70 / \mathrm{Ku} 80$ and catalytic subunit is known as a master protein in NHEJ [6].

Recently using high-density protein microarrays in the absence of DNA damage mimetics, PALF protein has been identified as the PARP2 substrate protein [7]. PALF protein is involved in the BER and NHEJ processes [8]. Physical interaction of PARP2 with DNA PK and PALF testifies in favor of PARP2 implication in NHEJ. However, it has been revealed that PALF functions in NHEJ together with PARP3, but not PARP2 [8].

In humans, DSBs appeared during V(D)J and CS recombination are processed mainly by Ku antigen dependent NHEJ; but in some specific conditions alt-NHEJ can be involved in CSR [5]. Interestingly, that both PARP1 and PARP2 are utilized in CSR process having specific and nonredundant functions, while PARP1 facilitates alt-NHEJ, PARP2 suppresses IgH/c-myc translocations during CSR [9].

In addition, PARP1 and PARP2 are required for hydroxyurea-induced homologous recombination to reactivate stalled replication forks [10]. The authors proposed that PARP1 and PARP2 detect disrupted replication forks and attract Mre11 to produce ssDNA via resection; then RAD51 is loaded that induces subsequent HR and restart of replication forks.

Using DNA duplexes with different DNA structures mimicking DNA intermediates of various DNA dependent processes it has been recently shown that PARP2 displays the lowest affinity to blunt end DSB (NHEJ substrate) and this DNA is the poorest activator of PARP2, while PARP2 binds to and is activated better with DNAs, which can be considered as DNA intermediates of BER, HR and DNA replication [11].

Thus, although an evidence of direct involvement of PARP2 in DSBR is missed, one could not deny out its participation in this process, at least under certain circumstances.

Acknowledgements. This work was supported by State contract 16.512.11.2241, RFBR (10-04-01083), and program «Molecular and cellular biology».

С. Н. Ходирева, М. М. Кутузов, О. І. Лаврик

Роль полі(ADP-рибоза)полімерази 2 у репарації ДНК

Резюме

Полі(АDР-рибозил)ювання - иее посттрансляційна модифікація білків, яка є надзвичайно важливою для підтримки стабільності геному і виживання клітин з пошкодженою ДНК. Полі(ADP-рибозил)ювання здійснюється ферментами полі(АDP-рибоза)полімеразами (PARP), які, використовуючи $\mathrm{NAD}^{+}$як субстрат, синтезують полімер ADP-рибози, ковалентно приєднаний до ядерних білків, у тому числі самим PARP. Наразі до сімейства PARP відносять велику кількість білків, з-поміж яких PARP1 є найвисококопійнішим і добре вивченим. Незважаючи на постійну появу даних стосовно значущзості РАRР для клітинних процесів, роль PARP2 - найближчого гомолога PARP1 - у різних шляхах репарації ДНК недостатньо охарактеризована. В огляді сумовано 
отримані in vivo ma in vitro дані щзоо участі PARP2 в спеціалізованих проиесах репараиії ДНК - ексичиійної репарачії основ і репарачії дволанцюгових розривів ДНК.

Ключові слова: полі(АDР-рибозо)полімераза 2, полі(АDР-рибозил)ювання, репарачія ДНК.

\section{С. Н. Ходырева, М. М. Кутузов, О. И. Лаврик}

Роль поли(ADP-рибоза)полимеразы 2 в репарации ДНК

Резюме

Поли(АDР-рибозил)ирование - это посттрансляцчионная модификаиия белков, чрезвычайно важная для поддержания стабильности генома и выживания клеток с поврежденной ДНК. Поли (АDP-рибозил)ирование осуществляется ферментами поли(ADPрибоза)полимеразами (PARP), которые, используя $\mathrm{NAD}^{+}$в качестве субстрата, синтезируют полимер ADP-рибозы, ковалентно присоединенный к ядерным белкам, в том числе самим PARP. B настоящее время к семейству PARP относят большое количество белков, среди которых PARP1 является наиболее высококопийным и хорошо изученным. Несмотря на постоянное появление данных о значимости РARP для клеточных прочессов, роль PARP2 ближайтего гомолога PARP1 - в различных путях репарации ДНК недостаточно охарактеризована. В обзоре суммированы полученные in vivo $u$ in vitro данные об участии PARP2 в специализированных процессах репарации ДНК-эксиизионной репарации оснований и репарации двухиепочечных разрывов ДНК.

Ключевые слова: поли(АDР-рибозо)полимераза 2, поли(ADPрибозил)ирование, репарация ДНК.

\section{REFERENCES}

1. Hassa P. O., Haenni S. S. Elser M., Hottiger M. O. Nuclear ADP-ribosylation reactions in mammalian cells: Where are we today and where are we going? // Microbiol. Mol. Biol. Rev.-2006.-70, N 3.-P. 789-829.

2. Ame J. C., Rolli V., Schreiber V., Niedergang C., Apiou F., Decker P., Muller S., Hoger T., Menissier-de Murcia J., de Murcia $G$. PARP-2, A novel mammalian DNA damage-dependent poly
(ADP-ribose)polymerase // J. Biol. Chem.-1999.-274, N 25.P. $17860-17868$.

3. Scharer O. D. Chemistry and biology of DNA repair // Angewandte Chemie.-2003.-42, N 26.-P. 2946-2974.

4. Schreiber V., Ricoul M., Ame J. C., Dantzer F., Meder V. S., Spenlehauer C., Stiegler P., Niedergang C., Sabatier L. PARP-2, structure-function relationship // Poly(ADP-ribosyl)ation / Ed. A. Burkle.-Georgetown: Landes Bioscience, 2004.-P. 13-31.

5. Mladenov E., Iliakis $G$. Induction and repair of DNA double strand breaks: the increasing spectrum of non-homologous end joining pathways // Mutat. Res.-2011.-711, N 1-2.-P. 61-72.

6. Isabelle M., Moreel X., Gagne J. P., Rouleau M., Ethier C., Gagne P., Hendzel M. J., Poirier G. G. Investigation of PARP-1, PARP-2, and PARG interactomes by affinity-purification mass spectrometry // Proteome Sci.-2010.-8.-P. 22.

7. Troiani S., Lupi R., Perego R., Depaolini S. R., Thieffine S., Bosotti $R$., Rusconi L. Identification of candidate substrates for poly(ADP-ribose)polymerase-2 (PARP2) in the absence of DNA damage using high-density protein microarrays // FEBS J.2011.-278, N 19.-P. 3676-3687.

8. Rulten S. L., Fisher A. E. O., Robert I., Zuma M. C., Rouleau M., Ju L., Poirier V., Reina-San-Martin V., Caldecott K. W. PARP-3 and APLF function together to accelerate nonhomologous endjoining // Mol. Cell.-2011.-41, N 1. -P. 33-45.

9. Robert I., Dantzer F., Reina-San-Martin B. Parp1 facilitates alternative NHEJ, whereas Parp2 suppresses IgH/c-myc translocations during immunoglobulin class switch recombination // J. Exp. Med.-2009.-206, N 5.-P. 1047-1056.

10. Bryant H. E., Petermann E., Schultz N., Jemth A. S., Loseva O., Issaeva N., Johansson F., Fernandez S., McGlynn P., Helleday $T$. PARP is activated at stalled forks to mediate Mre11-dependent replication restart and recombination // EMBO J.2009.-28, N 17.-P. 2601-2615.

11. Kutuzov M. M., Ame J.-C., Khodyreva S. N., Schreiber V., Lavrik $O$. I. Interaction of PARP2 with DNA structures mimicking DNA repair intermediates // Biopolym. Cell.-2011.-27, N 5.P. 383-386.

Received 15.01.12 